\title{
ANALISIS PAKAR TERHADAP TINGKAT TURBULENSI LINGKUNGAN ORGANISASI BISNIS TELEKOMUNIKASI SELULAR DI INDONESIA
}

\author{
Dwi Idawati \\ Program Pasca Sarjana \\ Sekolah Pasca Sarjana IPB \\ Arya Hadi Dharmawan \\ Sekolah Pasca Sarjana IPB \\ Setiadi Djohar \\ Sekolah Pasca Sarjana IPB \\ Sjafri Mangkuprawira \\ Guru Besar Ilmu Sosial dan Ekonomi IPB
}

\begin{abstract}
The key challenge for the telecommunication business industry in the global world's is "assuring competitiveness and profitability" for their companies in turbulent environments. Never in history has the pace of change in the business environment been as rapid as it is now. Recent developments such as the global marketplace, customers' demands that are differentiated by different buying power and product preferences in this environment, technological leadership is one of the key success factor. New technologies and new industries develop rapidly and customers are prepared to pay for the most newest technology. The company's strengths and successful strategies of the corporate leadership in the past are likely to remain relevant in the future. The research findings revealed that the turbulent environment level in the mobile telecommunication industry was in the discontinuous -strategic level, where the future is not extension of the past. This environment situation facing by Indonesia's telecomunication industry need the corporate leadership to challenge the organisation survival. This research is based on the qualitative descriptive method by using data obtained from telecommunication industry experts and secondary data.
\end{abstract}

Keywords:

Environment turbulence, Telecommunication industry 


\section{PENDAHULUAN}

\section{$1.1 \quad$ Latar Belakang}

Perkembangan sepuluh tahun terakhir di bidang information, communication dan telecommunication (ICT) menjadi dasar untuk lompatan yang lebih besar dan memberi dampak yang luas serta secara dramatis mengubah inovasi dunia. Indonesia dengan jumlah penduduk yang sangat besar dan wilayah geografis yang luas, merupakan pasar yang potensial bagi industri di sektor telekomunikasi. Seiring perkembangan jaman, maka dapat dilihat bahwa informasi, komunikasi, telekomunikasi dan teknologi, memungkinkan untuk dapat meningkatkan produktivitas, menghubungkan orang-orang dan masyarakat, serta meningkatkan standar kualitas kehidupan dan kesempatan kerja di seluruh dunia. Perubahan bidang ICT selain mengubah gaya hidup manusia, dalam berinteraksi dan bekerja, ICT telah terbukti menjadi prasyarat utama untuk meningkatkan daya saing ekonomi dan modernisasi sosial serta instrumen penting untuk dapat menjembatani ekonomi dan sosial dalam mengurangi tingkat kemiskinan.

Dampaknya dapat dikelompokkan menjadi sedikitnya dalam tiga kategori yang berbeda yaitu ekonomi, bisnis, dan sosial. Ketiganya saling terkait, dalam arti bahwa apa yang terjadi dimasing-masing katagori, merupakan sebab dan akibat. Bila diihat dari tingkat kesiapan Indonesia dalam bidang ICT, telah terjadi pelonjakan yaitu melompat dari peringkat 67 menjadi 53 (dari 138 negara yang diteliti) dan mengalami perbaikan di tiga komponen Network Readiness Index (NRI), yaitu meningkatkan skor negara secara keseluruhan dari skor 3,7 menjadi 3,9. Kesiapan ICT di Indonesia tercatat mempunyai kekuatan relatif. Sementara peringkat kesiapan individu sangat tinggi dibandingkan dengan tingkat negara, yaitu di peringkat 18, hal tersebut dimungkinkan karena standar mutu pendidikan semakin baik, sehingga ICT dapat terjangkau. Kondisi tersebut ke depannya, tentu akan membantu dalam meningkatkan penetrasi ICT serta penggunaannya yang saat ini masih rendah yaitu di peringkat 80 (dari 138 negara yang diteliti), dalam kenyataannya mendorong pemerintah menempatkan ICT dalam agenda pembangunan jangka panjangnya. (Dutta S, dan Mia I, 2011).

Industri telekomunikasi di Indonesia, khususnya para operator selular akan menghadapi peningkatan persaingan di antara para pemain, baik pemain lama, maupun baru yang mengakibatkan terbentuknya rancangan harga yang inovatif dan jumlah pelanggan prabayar yang meningkat dengan cepat. Sementara itu, teknologi generasi mendatang sedang dikembangkan dan diuji sebagai upaya memenuhi kebutuhan untuk meningkatkan kecepatan dan kapasitas. Menurut Rajagopal (2011), Research Associate dari Frost \& Sullivan dalam laporan berjudul Globalisation and Consolidation of the Telecom Industry: Mobile and Wireless Perspective. internet adalah model komunikasi yang merupakan ancaman bagi industri telekomunikasi selular di Indonesia. Internet dapat menarik pelanggan dengan jaminan layanan dan penyebaran informasi yang cepat dibandingkan layanan selular sebatas SMS (Short Message Service) atau telepon dua arah.

Selain itu dengan adanya kecenderungan komunikasi baru yang mengedepankan model komunikasi melalui situs jejaring sosial (Facebook, Twitter, MySpace, Skype, Blogspot) telah merubah pola komunikasi dari individu ke individu yang lainnya menjadi dari kelompok satu ke kelompok yang lainnya. Perubahan tersebut membuat adanya penetrasi antara 
komunikasi nirkabel dengan layanan broadband. Selanjutnya Rajagopal menyatakan, bahwa para pemain baru tidak berada dalam posisi untuk berinvestasi pada pengembangan infrastruktur generasi berikutnya. Hal ini mengakibatkan pemain baru bergabung dengan pemain pasar terkemuka lainnya yang memiliki dana yang diperlukan untuk memanfaatkan infrastruktur generasi berikutnya.

Rachmat (2011) Senior Consultant,
Information and Communication
Technologies, Frost \& Sullivan Indonesia, mengatakan bahwa dengan masuknya pemain baru di pasar telekomunikasi telah mengakibatkan terjadinya persaingan harga yang signifikan. Untuk mendapatkan pangsa pasar, pendatang baru umumnya mengurangi tarif, yang berujung pada penurunan average revenues per user (ARPU). Persaingan yang ketat ini telah memperluas jumlah pilihan yang tersedia bagi konsumen, dan memicu kecenderungan tingkat churn (berhenti berlangganan) yang tinggi. Dengan demikian, upaya meretensi pelanggan merupakan agenda yang penting bagi para organisasi bisnis telekomunikasi selular.

Berdasarkan kondisi-kondisi yang telah diuraikan tersebut di atas, maka dinamika organisasi menjadi pertimbangan utama. Situasi yang dihadapi organisasi bisnis merupakan tantangan dengan tingkat ketidakpastian situasi yang cukup tinggi dan lingkungan persaingan bisnis yang tidak ada batasannya lagi. Kondisi tersebut mengakibatkan organisasi membutuhkan kemampuan dalam pengamatan, menyesuaikan diri secara sistematis dan berkesinambungan terhadap perubahan lingkungan organisasi bisnis, baik lingkungan internal, maupun eksternal. Dengan mengetahui perubahan-perubahan yang terjadi, organisasi bisnis dapat melakukan antisipasi dalam menanggapi tantangan-tantangan eksternal dengan cara- cara yang tepat sebagai upaya menghindari resiko terburuk, yaitu kebangkrutan usaha.

Kesiapan organisasi dalam menghadapi era globalisasi juga menjadi hal yang erat kaitannya dengan kemampuan perusahaan dalam berkompetisi dan bekerja sama untuk memenuhi kebutuhan, di mana sumber daya manusia (SDM) dan kemampuan manusia untuk berinteraksi dengan lingkungan menjadi faktor penting.

Hal tersebut betul-betul merupakan elemen yang kritis bagi organisasi bisnis untuk dapat mempertahankan keunggulan dalam bersaing. Kemampuan organisasi untuk dapat beradaptasi dengan lingkungan eksternal tidak dapat secara efektif meningkatkan efisiensi manajemen bisnisnya. Sebagai akibatnya diperlukan kemampuan mengkoreksi aktivitas bisnis secara terus-menerus dan pengembangan strategis sebagai mekanisme untuk memperkirakan kecenderungan aktual atas perubahan-perubahan lingkungan (Gardiner dan Whiting, 1997).

Menurut Garvin (1993) agar organisasi bisnis dapat bertahan dalam menghadapi persaingan, organisasi bisnis harus secara konstan meningkatkan caracaranya dalam menjalankan bisnis. Tetapi, dalam kenyataannya banyak organisasi bisnis mengalami kegagalan dan kurang berhasil dalam menjalankan program peningkatan kinerja. Hal tersebut disebabkan karena banyak manajer tidak memahami bahwa, upaya untuk meningkatkan keberlanjutan organisasi bisnis dibutuhkan komitmen dalam pembelajaran. Akhirnya, bagaimana mungkin organisasi bisnis dapat menanggapi secara kreatif atas munculnya berbagai tantangan-tantangan baru seperti, berubahnya keinginan pelanggan atas produk dan jasa atau kecenderungan menurunnya pasar, tanpa pertama-tama menemukan sesuatu yang baru, kemudian mengubah 
cara-cara operasional yang merefleksikan pengetahuan baru.

De Geus (2002) melakukan penelitian terhadap organisasi bisnis yang berusia lebih dari 200 tahun. De Geus menemukan karakteristik pada umumnya penyebab organisasi bisnis berumur pendek, terutama karena organisasi bisnis tidak mampu belajar atau tidak mampu menyesuaikan diri dengan tuntutan perubahan lingkungan dan jaman, sehingga seringkali mengecewakan konsumen dan pada akhirnya 'mati' karena kehilangan pasar atau tutup karena ditolak oleh masyarakat dan lingkungannya.

Menurut Weiss dan Molinaro (2005), kinerja organisasi saat ini mengalami plateau dan bila organisasi tidak melakukan perubahan, akan memperburuk kondisi organisasi dalam arti semakin menurunnya kinerja organisasi. Dalam menghadapi kondisi tersebut, organisasi perlu mengembangkan berbagai strategi yang dapat membantu organisasi dalam melakukan transformasi. Fokus organisasi umumnya adalah bagaimana mengimplementasikan: 1) strategi inovasi antara lain pengembangan produk dan jasa baru, perubahan proses dan lainnya, 2) mengantisipasi perubahan-perubahan lingkungan yang secara signifikan dapat berdampak pada aktivitas internal organisasi seperti memindahkan pengetahuan dan praktek-praktek manajemen dalam organisasi.

\subsection{Perumusan Masalah}

Berdasarkan uraian tersebut diatas, maka di rumuskan permasalahan penelitan, yaitu apa saja tantangan-tantangan yang dihadapi organisasi bisnis telekomunikasi selular di Indonesia dan seberapa besar pengaruh lingkungan eksternal yang dihadapinya.

\subsection{Tujuan Penelitian}

Dari permasalahan diatas, maka tujuan dari penelitian ini adalah:

1. Teridentifikasikannya faktor-faktor lingkungan eksternal yang berpengaruh dan berdampak terhadap organisasi bisnis telekomunikasi selular.

2. Teridentifikasikannya tingkat turbulensi lingkungan organisasi bisnis telekomunikasi selular di Indonesia.

\subsection{Manfaat Penelitian}

Manfaat dari penelitian ini bagi organisasi bisnis telokomunikasi selular adalah :

1. Menjadi masukan bagi organisasi bisnis telekomunikasi selular untuk selalu mempertahankan keunggulan dalam bersaing melalui kemampuan beradaptasi dengan perubahan lingkungan.

2. Memberi kontribusi dalam menambah referensi bagi peneliti berikutnya yang akan melakukan penelitian di bidang manajemen strategi terkait dengan kemampuan organisasi dalam menghadapi tantangan-tantangan.

\section{TINJAUAN PUSTAKA}

\subsection{Organisasi Bisnis dan Lingkungan Bisnis \\ George dan Jones (2002),} menyebutkan sejumlah faktor lingkungan eksternal yang mendorong perubahan, yakni kekuatan: kompetisi, ekonomi, politik, globalisasi, sosial-demografis, dan etikal. Dewasa ini, persaingan dalam dunia bisnis berlangsung semakin ketat. Dinamika ekonomi dan politik nasional, baik regional, maupun global bergerak sangat fluktuatif dan penuh kejutan. Globalisasi ekonomi dan budaya yang dipicu oleh perkembangan yang pesat atas teknologi informasi, komunikasi dan telekomunikasi telah menyebabkan 
dunia ini bagaikan desa global (global village).

Organisasi bisnis dapat saja berbeda dalam berbagai hal, tetapi organisasi bisnis pada umumnya mempunyai pemahaman yang sama dalam hal mentransformasikan faktor input menjadi output. Proses transformasi ini dilakukan sebagai upaya menghadapi pengaruh-pengaruh dari kondisi lingkungan yang dapat berpengaruh pada perusahaan dan juga pada aktivitas-aktivitas perusahaan. Lingkungan eksternal perusahaan sangat kompleks, bergejolak dan interaktif, tetapi tidak bisa diabaikan fakta bahwa kondisi lingkungan eksternal organisasi bisnis akan berdampak terhadap aktivitas internal perusahaan.

Konstelasi perubahan lingkungan mengakibatkan tekanan yang tinggi terhadap organisasi bisnis saat ini, sebagai organisasi bisnis secara fundamental merasa perlu untuk merubah fokus dan orientasinya. Kondisi tersebut merealisasikan perkembangan dalam lingkungan baru bahwa, organisasi tidak hanya sekadar bertahan (survive), tetapi juga didorong untuk unggul agar dapat memastikan kontinuitas dan bertahan (Hitt, 1996; Peters dan Waterman, 1982). Jamali dan Sidani (2005) mengatakan bahwa telah terjadi perubahan fokus organisasi bisnis lama ke baru.

\subsection{Analisis Enviromental Scanning}

Analisis lingkungan merupakan akuisisi dan penggunaan informasi tentang peristiwa, tren, dan hubungan dalam lingkungan eksternal organisasi. Pengetahuan yang akan membantu manajemen dalam merencanakan arah tindakan bagi masa depan organisasi. Menurut Choo (2001) semua lingkungan bisnis eksternal yang terdiri dari tiga aspek: (1) Lingkungan makro, (2) Lingkungan industri, dan (3) Lingkungan. Analisis lingkungan eksternal industri dapat memberikan gambaran yang jelas tentang peluang dan ancaman yang dihadapi oleh pemain dalam industri. Hasil analisis lingkungan memberi nilai yang berarti bagi organisasi untuk menyusun rencana strategi perusahaan.

\subsection{Lingkungan Industri dan Strategi Bersaing}

Menurut Porter (1980), aspek lingkungan industri akan lebih mengarah pada aspek-aspek persaingan dimana organisasi bisnis berada. Porter mengemukakan konsep strategi bersaing dengan menganalisis persaingan organisasi bisnis berdasarkan pada lima kekuatan dalam bersaing. Kelima aspek atau variabel yang membentuk model untuk strategi bersaing adalah sebagai berikut, (1) Ancaman masuknya pendatang baru, (2) Persaingan sesama perusahaan dalam industri, (3) Ancaman produk substitusi, (4) Kekuatan tawar-menawar pembeli, dan (5) Kekuatan tawar-menawar pemasok.

\subsection{Analisis Tingkat Turbulensi Lingkungan Organisasi Bisnis \\ Ansoff dan McDonnell (1990),} menawarkan suatu pendekatan dalam melakukan analisis turbulensi lingkungan perusahaan. Cara menganalisis perubahanperubahan lingkungan bisnis, adalah dengan menganalisis dari sisi bagaimana manajemen perusahaan merespon kondisi lingkungan internal dan eksternalnya dengan menggunakan tolok ukur tertentu sehingga diketahui tingkat turbulensinya. Selanjutnya Ansoff dan McDonnell (1990) menyatakan bahwa turbulensi lingkungan merupakan suatu kumpulan ukuran dari suatu yang berubah-ubah (changeability), dapat diramalkan (predictability) atas lingkungan perusahaan, dan attributes lainnya. Changeability terdiri atas kompleksitas 
lingkungan dan kebaruan relatif dari tantangan berlanjut yang dihadapi perusahaan dalam lingkungannya. Predictability terdiri atas kecepatan perubahan, yaitu rasio kecepatan di mana tantangan berganti dalam lingkungan dengan kecepatan respons perusahaan dan kejelasan masa depan, dimana ketepatan dan kesesuaian informasi tentang masa depan berperan penting dan attributes lainnya yang merupakan faktor-faktor eksternal yang berpengaruh terhadap industri.

Menurut Ansoff dalam menganalisis tingkat kekuatan lingkungan eksternal digunakan penilaian yang diberi nilai 1 sampai 5, yang kemudian dapat diinterpretasikan, yaitu, repetitive (nilainya 1), expanding (nilainya 2), changing (nilainya 3), discontinuous (nilainya 4), dan surprising (nilainya 4).

Berdasarkan latar belakang yang ada dan tinjauan pustaka, maka dirancang model konseptual analisis turbulensi lingkungan organisasi bisnis. Berikut pada Gambar 1 . merupakan model konseptual analisis turbulensi lingkungan organisasi bisnis.

Kondisi Persaingan dan POLEKSOSBUDTEK

Changeability

1) Kompleksitas Lingkungan

2) Lingkungan Relatif

\section{Predictability}

1) Kecepatan Perubahan

2) Kejelasan Masa Depan

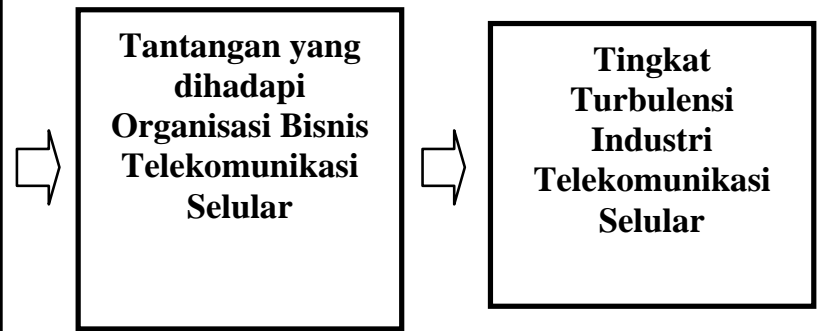

Attributes Lainnya

Gambar 1.

Model Konseptual Analisis Turbulensi Lingkungan Organisasi Bisnis

III. METODE PENELITIAN

\subsection{Lokasi dan Waktu}

Penelitian ini dilaksanakan di Jakarta, terhadap pakar telekomunikasi.
Pelaksanaan pengumpulan dan pengolahan data dilakukan seperti terdapat pada Tabel 1.:

Tabel 1.

Jadwal Pelaksanaan Penelitian

\begin{tabular}{|r||l||l||}
\hline \multicolumn{1}{|c||}{ No } & \multicolumn{1}{|c|}{ Kegiatan } & \multicolumn{1}{c|}{ Waktu } \\
\hline \hline 1 & Pengumpulan Data & Minggu ke-4 bulan Desember tahun 2011, \\
& & Minggu ke-2 bulan Februari tahun 2012 \\
\hline \hline 2 & Pengolahan Data & Minggu ke- 3 dan 4 bulan Februari tahun 2012 \\
\hline
\end{tabular}




\subsection{Kerangka Analisis Penelitian}

Kerangka analisis yang digunakan

dalam penelitian ini dapat dilihat pada

Gambar 2.

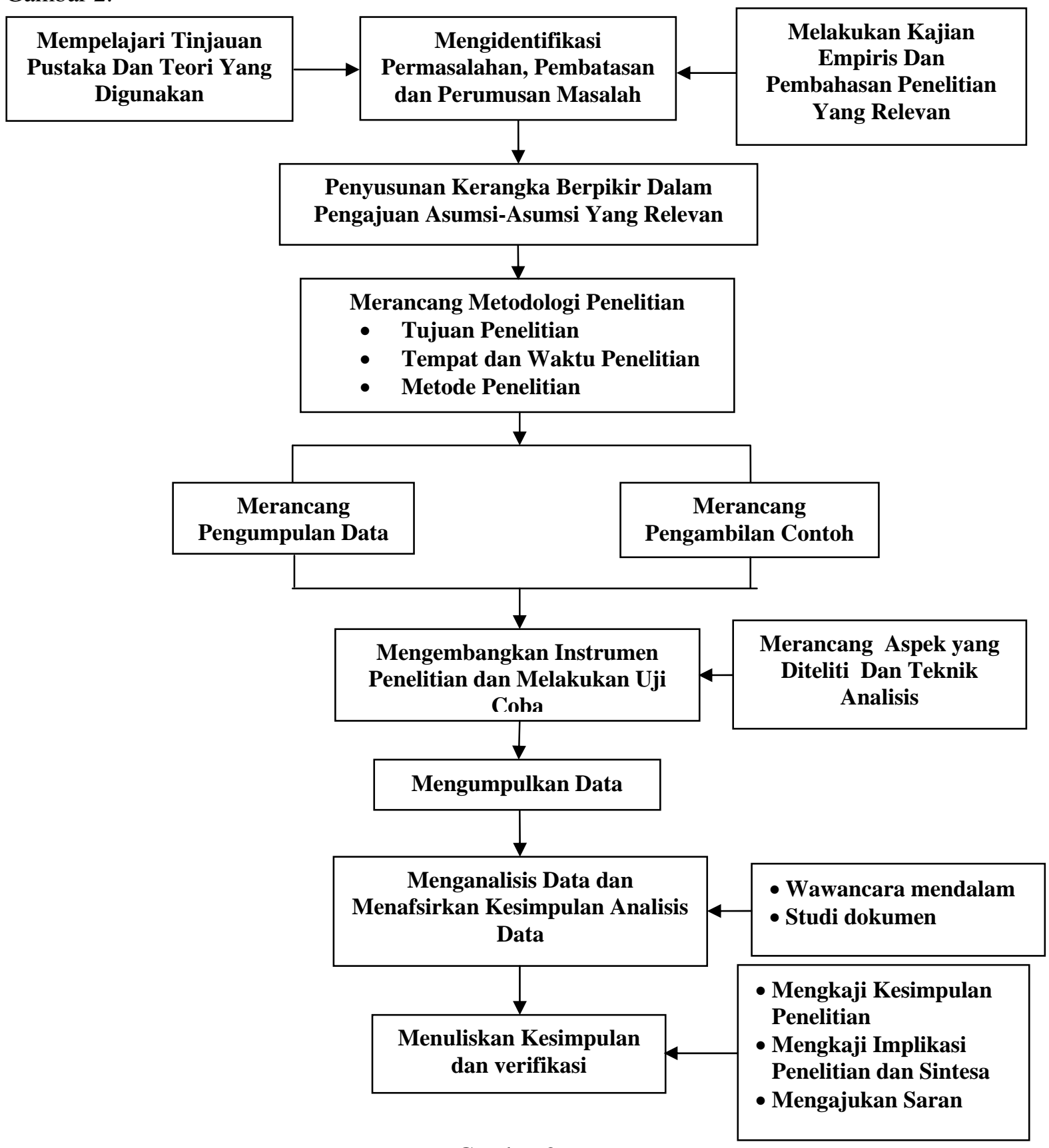

Gambar 2.

Kerangka Proses Penelitian 


\subsection{Metode Pendekatan Penelitian}

Penelitian ini menggunakan pendekatan deskriptif kualitatif dengan instrumen yang digunakan meliputi wawancara mendalam, dan studi data sekunder. Menurut Merriam (2009), penelitian kualitatif mempunyai ketertarikan dalam memahami bagaimana individu menginterpretasikan pengalamanpengalamannya, bagaimana individu membangun dunianya, dan memaknai atribut-atribut tersebut dalam pengalamannya.

Interpretasi penelitian kualitatif hampir semuanya mengasumsikan bahwa realitas merupakan pemahaman sosial. Finlay (2006) menyatakan bahwa penelitian kualitatif dilakukan dalam situasi tertentu yang ada dalam kehidupan nyata dengan tujuan menginvestigasi dan memahami fenomena apa yang terjadi, mengapa terjadi, dan bagaimana terjadinya. Jadi, penelitian kualitatif berbasis pada going explore yang melibatkan kedalaman dan berorientasi pada studi kasus, sejumlah kasus, atau kasus tunggal. Tujuan utama penelitian kualitatif adalah membuat fakta mudah dipahami dan bila memungkinkan dapat menghasilkan hipotesa baru.

\subsection{Teknik Pemilihan Narasumber}

Jumlah narasumber pakar dalam penelitian ini adalah 6 orang pakar yang dianggap menguasai industri telekomunikasi selular. Cara pemilihan narasumber adalah mengunakan pendekatan purposive and convinience sampling. Narasumber terdiri dari Presiden Direktur (owner), Direktur dan Vice President baik yang masih aktif dalam industri telekomunikasi selular maupun sudah tidak aktif lagi.

\subsection{Teknik Pengumpulan Data}

Penelitian ini menggunakan pendekatan deskriptif kualitatif dengan instrumen yang digunakan meliputi wawancara mendalam (in-depth interview), dan data sekunder. Dalam penelitian ini, jenis data dan sumber data yang diperlukan meliputi data primer dan data sekunder. Data primer yaitu data yang diperoleh melalui wawancara mendalam (in-depth interview), sedangkan data sekunder, yaitu data yang dapat digunakan untuk menginterpretasikan data primer. Berikut ini Tabel 2. menjelaskan tentang teknik pengumpulan data yang digunakan dalam penelitian ini.

Tabel 2.

Teknik Pengumpulan Data Primer dan Sekunder

\begin{tabular}{|c|c|c|}
\hline Narasumber & Tujuan & Teknik \\
\hline $\begin{array}{l}\text { Primer } \\
\text { Pakar dalam bidang } \\
\text { telekomunikasi selular ( lima } \\
\text { orang) dan bukan karyawan dari } \\
\text { PT. PQR dan PT. XYZ. }\end{array}$ & $\begin{array}{l}\text { Mendapatkan pandangan atau pendapat atas } \\
\text { analisis lingkungan organisasi bisnis dan } \\
\text { tantangan-tantangan yang di hadapi oleh } \\
\text { organisasi bisnis telekomunikasi selular. }\end{array}$ & $\begin{array}{l}\text { Wawancara } \\
\text { mendalam }\end{array}$ \\
\hline $\begin{array}{l}\text { Sekunder } \\
\text { Eksternal Organisasi }\end{array}$ & $\begin{array}{l}\text { Data industri telekomunikasi di Indonesia } \\
\text { maupun global, regulasi pemerintah } \\
\text { berkaitan dengan industri telekomunikasi } \\
\text { selular, peluang dan tantangan yang dihadapi } \\
\text { industri telekomunikasi selular dimasa } \\
\text { mendatang. }\end{array}$ & \\
\hline
\end{tabular}




\subsection{Teknik Analisis Data}

Pengolahan data berdasarkan hasil dari wawancara mendalam (in-depth interview) dan data sekunder. Teknis analisis data yang digunakan adalah pendekatan content analysis. Cara kerja dan tahap menganalisis data dengan pendekatan content analysis yang digunakan dalam penelitian ini dapat dilihat pada Tabel 3.

Tabel 3.

Tahapan Analisis Data

\begin{tabular}{||r||l||l||}
\hline \multicolumn{1}{|c|}{ Tahap } & \multicolumn{1}{|c||}{ Tindakan } & \multicolumn{1}{|c||}{ Rincian Tindakan } \\
\hline \hline 1 & $\begin{array}{l}\text { Mengorganisasi data yang diperoleh dari hasil } \\
\text { wawancara dan data sekunder. }\end{array}$ & Mengumpulkan data primer dan sekunder. \\
\hline 2 & $\begin{array}{l}\text { Merekam hasil wawancara mendalam } \\
\text { kemudian disusun transkrip (verbatim). }\end{array}$ & $\begin{array}{l}\text { Menetentukan katagorisasi, konsep, tema } \\
\text { dan pola. }\end{array}$ \\
\hline 3 & $\begin{array}{l}\text { Melakukan pengkodean berdasarkan hasil dari } \\
\text { pengorganisasian data. }\end{array}$ & $\begin{array}{l}\text { Menganalisis dan menentukan berbagai } \\
\text { tema dan keterkaitan antara satu tema } \\
\text { dengan tema yang lain. Tema utama yang } \\
\text { muncul akan memudahkan untuk dilakukan } \\
\text { interpretasi dan analisis. }\end{array}$ \\
\hline 5 & $\begin{array}{l}\text { Melakukan pemahaman dan pengujian, yaitu } \\
\text { proses berupa pemotongan data hasil } \\
\text { wawancara dan dimasukkan dalam folder } \\
\text { sesuai dengan tema atau pola yang ada. }\end{array}$ & $\begin{array}{l}\text { Mendapatkan hasil dari studi dokumen } \\
\text { dimasukkan dalam folder yang sama untuk } \\
\text { mendukung pemahaman atas } \\
\text { hasil } \\
\text { wawancara mendalam. }\end{array}$ \\
\hline 5 & $\begin{array}{l}\text { Melakukan interpretasi. } \\
\text { Menganalisis data, yaitu mengkaitkan } \\
\text { antara teori yang ada sehingga interpretasi } \\
\text { tidak bersifat bias tetapi dapat menjelaskan } \\
\text { teori. }\end{array}$ \\
\hline \hline
\end{tabular}

\subsection{Pengujian Validitas dan}

\section{Reliabilitas Hasil Penelitian}

Hasil dari penelitian ini menggunakan uji kredibilitas, yaitu melalui pendekatan triangulation, dengan cara menggunakan pengujian atas data yang diperoleh dengan berbagai sumber, dan teori. Tujuannya agar informasi yang disajikan memiliki konsistensi. Oleh karena itu, digunakan lebih dari satu teori, dan lebih dari satu metode pengumpulan data yaitu wawancara dan analisis dokumen. Di samping itu, dilakukan juga cara member checking yaitu dengan cara setiap temuan didiskusikan dan dicek validitasnya dengan pakar yang lain untuk mengetahui fenomena yang diteliti.

\section{HASIL DAN PEMBAHASAN}

\subsection{Analisis Pakar Terhadap Lingkungan Eksternal Berdasarkan Data Primer \\ Berdasarkan pendapat para pakar} tentang kondisi lingkungan eksternal, dapat disimpulkan adanya lima tema penting yang merupakan tantangan yang dihadapi oleh organisasi bisnis telekomunikasi selular. Tantangan terkait dengan 1) kebijakan pemerintah yang terkait dengan industri telekomunikasi selular, 2) produk dan kemajuan teknologi, 3) kompetisi pasar yang semakin ketat diantara operator telekomunikasi selular, 4) pelanggan dan konsumen, dan 5) industri telekomunikasi selular itu sendiri. Agar dapat menjamin kelangsungan pertumbuhannya, operator telekomunikasi selular perlu menjalankan 
berbagai pendekatan strategis. Berikut ini akan dibahas secara lebih mendalam masingmasing tema.

\subsubsection{Kebijakan Pemerintah}

Tema pertama, yaitu kebijakan pemerintah. Berdasarkan hasil wawancara dengan pakar, diperlukan kebijakan pemerintah yang dapat mengatasi keterbatasan frekuensi (pita lebar) yang dapat menanggulangi permasalahan dalam menghadapi perkembangan teknologi 3G dan 4G, tujuan lainnya adalah untuk menangani permasalahan koneksi dan interkoneksi yang dialami oleh para operator telekomunikasi selular. Begitu pula dengan peran Komisi Pengawas Persaingan Usaha (KPPU) dan Badan Regulasi Telekomunikasi Indonesia (BRTI) yang dianggap belum maksimal dalam mengatasi berbagai permasalahan dalam pelayanan, perang harga, dan pencurian pulsa. Berikut ini petikan pernyataan para pakar terkait dengan tema kebijakan pemerintah:

"Adanya

keterbatasan

sumberdaya yaitu, tentang masalah frekuensi, sementara itu Pemerintah hanya menunjuk pemain-pemain tertentu yang diijinkan menggunakan frekuensi tertentu. Sudah saatnya pemerintah untuk menambah frekuensi, karena frekuensi yang ada saat ini sudah tidak memadai lagi”.

"Kondisi akhir-akhir ini dirasa kurang menguntungkan oleh para operator telekomunikasi adalah, kurang berfungsinya KPPU(Komisi Pengawas Persaingan Usaha) dan BRTI (Badan Regulasi Telekomunikasi Indonesia), tidak membatasi terhadap harga yang akhirnya mengakibatkan terjadinya perang harga diantara operator

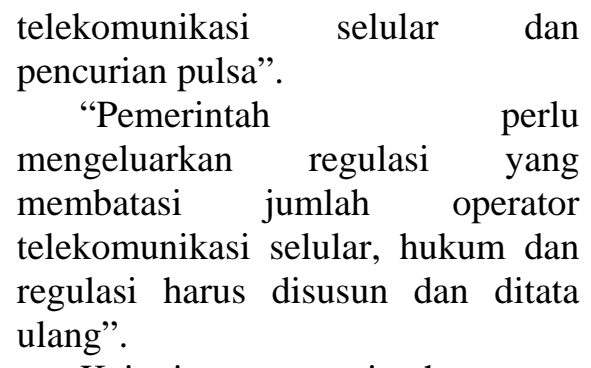

Keinginan pemerintah agar para operator telekomunikasi selular terlibat dalam mega proyek Palapa Ring yang memiliki nilai sangat strategis untuk mempercepat pembangunan prasarana telekomunikasi terutama di wilayah Indonesia bagian timur merupakan salah satu kebijakan pemerintah. Hal ini dikarenakan proyek Palapa Ring membutuhkan dana yang besar dan dalam jumlah triliunan rupiah, proyek tersebut akan dapat terwujud apabila perusahaanperusahaan telekomunikasi selular dapat berkontribusi besar terhadap proyek tersebut. Berikut adalah petikan hasil wawancara dengan pakar:

"Proyek Pemerintah dalam membangun Palapa Ring jaringan optik yang mengelilingi Indonesia, sehingga semua pulau besar di Indonesia akan tersambung. Pemerintah menginginkan semua operator berkontribusi terhadap pembangunan mega proyek tersebut. Proyek ini membutuhkan dana yang besar trilyun”

Pakar menyatakan bahwa ke depan, setiap operator telekomunikasi selular harus memenangkan persaingan, tetapi prinsip berkolaborasi juga dimungkinkan, karena biaya untuk membangun tower dan membangun jaringan memerlukan dana yang sangat besar. Untuk itu, organisasi bisnis telekomunikasi selular perlu menggalang kerjasama sebagai upaya efisiensi nasional. Berikut petikan pernyataan pakar: 
"Jadi satu contoh bahwa memang pembangunan fiber optik dan tower serta kolaborasi yang lainnya sangat dimungkinkan, bahkan sampai modus pemasaran bersama itu sangat dimungkinkan, misalnya mobile 8 dengan Indosat IM2 (Indosat Multimedia Mobile). Jadi branding namanya IM2 Mobile 8 , jaringan memakai mobile 8 , tapi yang menjual IM2. Modusnya IM2 mau beli bulk traffic atau revenue sharing”.
"Kami juga bekerja sama dengan menyewa fiber optik yang dimiliki oleh PLN, XL, Indosat dan Telkomsel”.

Berdasarkan penjelasan-penjelasan mengenai tema kebijakan pemerintah, maka dapat dibuat skema kebijakan pemerintah berdasarkan pendapat para pakar, terkait dengan kondisi lingkungan eksternal industri telekomunikasi selular, seperti terlihat pada Gambar 3. Pada Gambar 3. tersebut, terdapat enam butir tema pada kebijakan pemerintah yang terkait dengan lingkungan eksternal industri telekomunikasi selular.

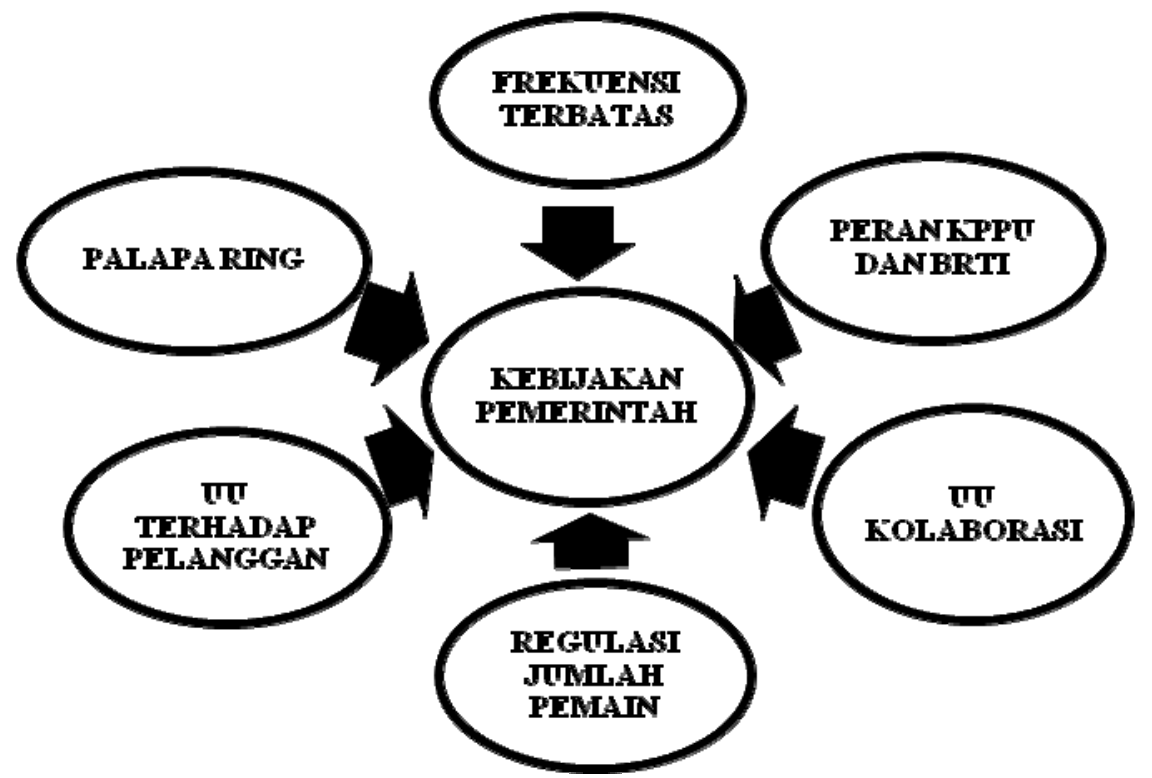

Gambar 3.

Tema : Kebijakan Pemerintah

\subsubsection{Produk dan Kemajuan Teknologi}

Tema yang kedua, yaitu terkait dengan produk dan kemajuan teknologi. Berdasarkan pendapat pakar, telah terjadi perkembangan teknologi yang sangat cepat, baik teknologi yang digunakan oleh GSM maupun CDMA, begitu pula dengan pergeseran penggunaan layanan. Berikut adalah petikan wawancara dengan pakar yang terkait dengan produk dan kemajuan teknologi.

"Perubahan teknologi yang digunakan oleh GSM, dimulai dari 2G, kemudian GPRS dan MMS, kemudian disempurnakan oleh EDGE (2,75G), kemudian 3G, lalu HSDPA $(3,5 G)$ dan yang terkini adalah 4G melalui teknologi LTE dengan kecepatan 42 Mpbs dan 
Wimax. Sedangkan CDMA 8001900 MHz".

"Perubahan teknologi sangat dinamis dan cepat. Perkembangannya tidak bisa diperkirakan, untuk mengetahui teknologi macam apa lagi yang akan muncul. Tren teknologi dimasa mendatang akan cepat usang”.

"Terjadinya perubahan penggunaan voice dan SMS menjadi layanan data akan berdampak pada teknologi yang digunakan. Nantinya akan berkembang teknologi gambar bergerak dan video. Telepon dan internet akan menjadi convergen”.

Seiring dengan berkembangnya piranti (devices) smartphone yang dapat digunakan untuk pemanfaatan layanan data tersebut. Berikut kata pakar tentang piranti smartphone.

"Era teknologi broadband akan menyebabkan bertumbuhnya piranti smartphone. Saat ini semakin banyak bermunculan smartphone buatan Cina yang harganya terjangkau masuk ke Indonesia”.

Berdasarkan penjelasan-penjelasan mengenai produk dan kemajuan teknologi yang bersumber dari para pakar, maka dapat diidentifikasi enam hal yang bersumber dari lingkungan eksternal industri seperti terlihat pada Gambar 4. layanan data, maka semakin dibutuhkan

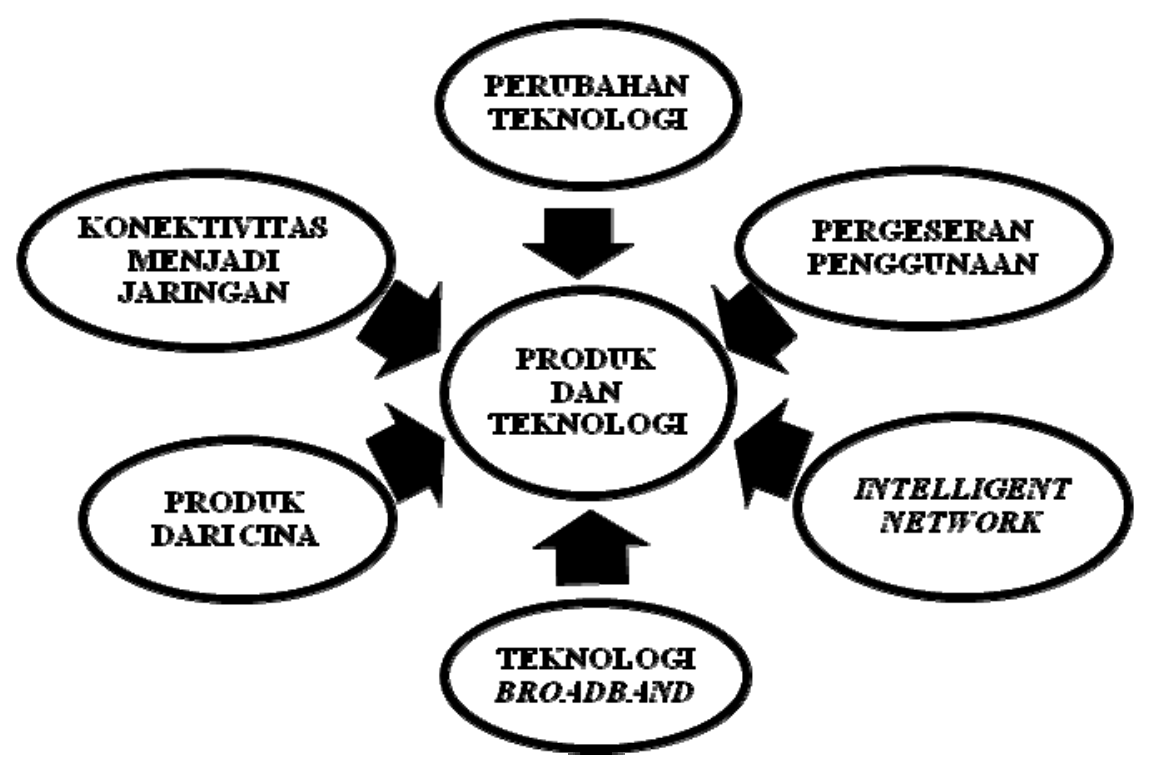

Gambar 4.

Tema : Produk dan Teknologi

\subsubsection{Kompetisi Pasar}

Tema ketiga, yaitu terkait dengan pasar. Berdasarkan pendapat pakar dikatakan bahwa persaingan diantara operator sangat ketat dengan jumlah operator yang relatif banyak, tetapi pangsa pasar dikuasai oleh 3 operator besar. Berikut petikan wawancara dengan pakar:

"Sebetulnya pasarnya kecil untuk masing-masing operator, karena pasar yang ada diperebutkan 
oleh banyak pemain, yaitu 11 operator telekomunikasi selular”.

"Namun demikian, 95\% pasar hanya dikuasai oleh 3 operator telekomunikasi terbesar di Indonesia, yaitu Telkomsel, Indosat dan XL Axiata”.

Selain itu pakar juga menyatakan bahwa telah terjadi perubahan atau pergeseran dalam penggunaan selular yaitu dari voice dan SMS berubah menjadi lanayan data. Berikut ini pendapat dari pakar:

"Penggunaan internet akan lebih besar daripada voice dan SMS di masa yang akan datang”.

"Terjadinya perubahan pemakaian voice dan SMS menjadi layanan data, dan ini membutuhkan konektivitas yang lebih besar dan akan memberikan ARPU yang lebih besar bagi para operator telekomunikasi selular”.

Indikasi yang menunjukkan terjadinya peningkatan layanan data adalah dengan meningkatnya penggunaan internet melalui handphone dan meningkatnya penggunaan jaringan sosial, seperti facebook, twitter, skype, dan lain sebagainya. Kapasitas pemakaian telekomunikasi selular mengalami peningkatan, dengan semakin banyaknya pemilik handphone di Indonesia dan permasalahan yang muncul adalah pada konektivitas. Berikut ini hasil wawancara dengan pakar:

"Data traffic terbesar di Indonesia adalah data mobile internet. Berdasarkan data tahun 2011 menunjukkan bahwa, di Indonesia terdapat 43 juta pengguna facebook".

"Pemilik handphone di Indonesia saat ini berjumlah 60\% dari jumlah penduduk Indonesia”.

"Luas jangkauan tetap, tetapi kapasitas bertambah seiring dengan meningkatnya jumlah pelanggan di tahun 2011 sekitar 205 juta pelanggan, yang sekarang terjadi adalah gangguan di konektivitas (kurang bagus koneksinya)”.

Dari penjelasan-penjelasan mengenai pasar yang bersumber dari para pakar, maka dapat diidentifikasi enam hal yang bersumber dari lingkungan eksternal industri seperti terlihat pada Gambar 5. 


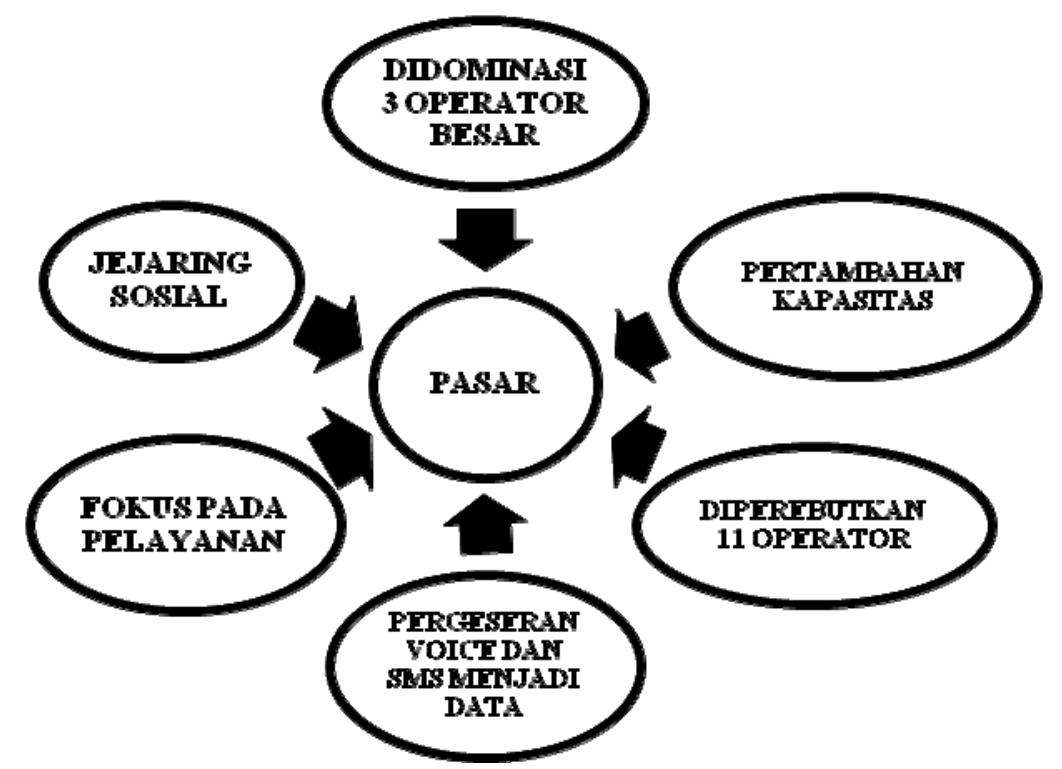

Gambar 5.

Tema : Pasar

\subsubsection{Pelanggan dan Konsumen}

Tema keempat, yaitu terkait dengan pelanggan atau konsumen. Menurut pakar, untuk memenangkan persaingan, maka para operator harus mengenali kebutuhan dan perilaku pelanggannya dengan baik. Berikut pendapat yang disampaikan oleh pakar:

"Terdapat dua jenis konsumen, yaitu konsumen low class yang tidak terlalu mempedulikan adanya gangguan atau kualitas koneksi, tetapi lebih mementingkan dari segi harga, dan ada konsumen yang high class yang sangat peduli dengan pentingnya kualitas koneksi yang bagus dan harga tidak menjadi masalah”.

Pada masa mendatang, jumlah pemakai layanan data akan meningkat. Hal tersebut diindikasikan dengan meningkatnya perilaku berkomunikasi melalui jejaring sosial, dibandingkan dengan penggunaan voice dan SMS. Begitu pula dengan jumlah pelanggan, dimana terjadi peningkatan dan didominasi oleh anak-anak muda.
Peningkatan penggunaan layanan data, berdampak pada kebutuhan piranti yang canggih (smartphone), sehingga akhir-akhir ini bermunculan smartphone buatan China dengan harga yang terjangkau. Berikut pendapat yang disampaikan oleh pakar:

"Pelanggan pengguna layanan data didominasi oleh anak muda".

"Hasil survei menyatakan bahwa anak-anak SD, SMP dan SMA lebih banyak menggunakan internet dibandingkan dengan orang dewasa”.

"Jumlah pelanggan di Indonesia pada tahun 2011, berjumlah 205 juta pelanggan, dan meningkatnya perilaku dalam berkomunikasi melalui jejaring sosial (facebook, twitter, skype, dan lain sebagainya)".

Para operator telekomunikasi selular dituntut untuk memiliki kemampuan mengenali kebutuhan-kebutuhan konsumen dengan cara mengembangkan fitur-fitur yang sesuai dengan kebutuhan konsumen. 
Selain itu, pelanggan juga sangat menuntut mendapatkan pelayanan yang berkualitas agar mereka dapat mengkonsumsi produkproduk yang dijual oleh para operator telekomunikasi selular dengan perasaan puas. Dari sisi perusahaan, kepuasan dan loyalitas pelanggan terhadap produk-produk artau jasa yang mereka keluarkan merupakan target utama pemasaran, yang akan berimplikasi kepada besarnya penjualan dan meningkatnya kinerja perusahaan. Berikut pandangan dari pakar:
"Fitur-fitur yang dikembangkan disesuaikan dengan consumer needs. Sekarang trennya tematik dan community based".

"Pelanggan akan merasa puas bila mendapat pelayanan yang berkualitas, seperti ada jasa customer care, service dan devices portfolio, cost and billing, network dan service quality".

Gambar 6 memperlihatkan secara ringkas tema pelanggan berdasarkan petikan pendapat pakar.

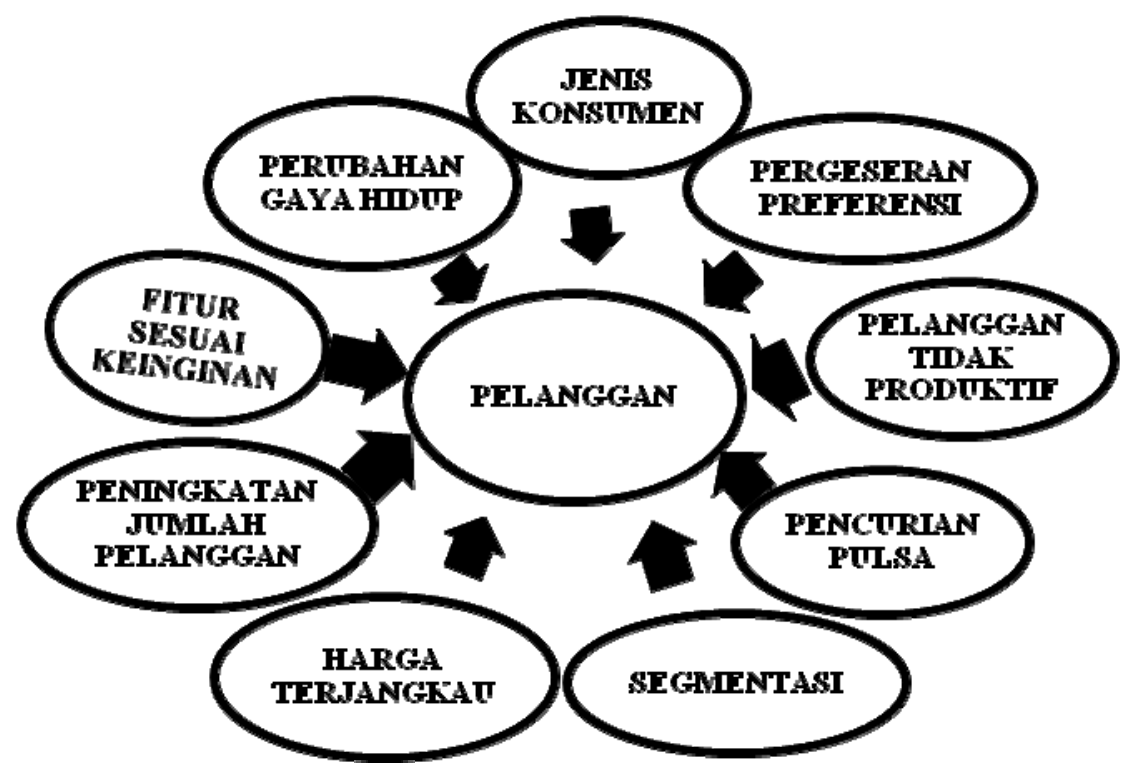

Gambar 6.

Tema : Pelanggan

\subsubsection{Industri Telekomunikasi}

Tema yang kelima, terkait dengan industri telekomunikasi. Berdasarkan wawancara dengan pakar, diperoleh gambaran bahwa ada dua budaya dalam industri telekomunisasi selular, dan kedua budaya ini akan berpengaruh terhadap tindakan yang akan dilakukan oleh organisasi bisnis telekomunikasi selular. Di samping itu, saat ini, hampir semua operator telekomunikasi selular berupaya meningkatkan pendapatannya melalui peningkatan jumlah pelanggan (volume based). Berikut pendapat pakar terkait dengan hal tersebut:

"Di dalam industri telekomunikasi selular terdapat dua budaya, yaitu tradisional Telko dan inovatif Telko. Tradisional Telko memiliki budaya yang lebih mengutamakan kemewahan, sedangkan inovatif Telko memiliki 
budaya organisasi lebih mengutamakan perubahan”.

"Masing-masing operator telekomunikasi selular berlombalomba meningkatkan jumlah pelanggan, dulu basisnya value sekarang basisnya volume”.

Di samping itu pakar juga mengatakan bahwa, industri telekomunikasi selular merupakan industri yang memiliki daya tarik bagi investor dalam berinvestasi di Indonesia. Hal tersebut ditunjukkan dengan peningkatan jumlah operator telekomunikasi di Indonesia. Selain itu regulasi atau kebijakan Pemerintah tidak membatasi jumlah operator telekomunikasi selular di Indonesia, karena regulasi Pemerintah titik awal semangatnya adalah menggerakkan iklim berinvestasi. Sebagai akibatnya, muncul sejumlah operator telekomunikasi di Indonesia. Jumlah operator telekomunikasi selular yang relatif banyak mengakibatkan terjadinya persaingan dalam mendapatkan pelanggan. Dengan tingkat persaingan yang tinggi, maka tidak mudah untuk berkolaborasi diantara operator telekomunikasi selular yang ada.

Berdasarkan keadaan yang terjadi saat ini, maka hal tersebut merupakan tantangan tersendiri yang dihadapi oleh setiap operator telekomunikasi selular dalam upaya menahan pelanggan lama dan mendapatkan pelanggan baru. Berikut petikan pendapat pakar terkait dengan hal tersebut:

"Bermunculan investor-investor asing dalam industri telekomunikasi selular di Indonesia”.

"Jumlah operator

telekomunikasi selular di Indonesia terlalu banyak, bila dibandingkan dengan Cina yang hanya tiga operator, Malaysia dan Singapura juga hanya tiga operator. Hal tersebut berakibat pada terjadinya persaingan yang sangat ketat diantara operator (perang harga). Yang bisa kita lihat adalah apa yang dilakukan pesaing, harus cepat direact oleh operator yang lain. Sebagai akibatnya, product life cycle menjadi lebih pendek, meningkatnya jumlah churn, dan akhirnya berdampak pada ARPU. Persaingan mendatang terutama pada content, dan pertumbuhan industri ini sangat cepat”.

"Kolaborasi tidak mudah dilakukan karena masing-masing investor memiliki kekuatan finansial dan adanya ego investor. Walaupun sebetulnya sangat memungkinkan berkolaborasi dalam pembangunan fiber optik dan tower, bahkan pemasaran bersama”.

Selain itu, pakar juga mengemukakan pendapat yang berkaitan dengan internal perusahaan yaitu tentang pentingnya peran pemimpin dalam organisasi telekomunikasi selular dan salah kunci keberhasilan organisasi telekomunikasi selular adalah memiliki SDM yang kompeten. Berikut petikan pendapat pakar terkait dengan hal tersebut:

"Perusahaan memerlukan pemimpin yang mempunyai visi, misi, dan value yang dapat mendorong karyawan untuk terus belajar dan beradaptasi dalam menghadapi perubahan-perubahan”.

"Organisasi membutuhkan pemimpin yang memiliki visi, dan dapat menjadi role model bagi pengikutnya".

"Salah satu kunci keberhasilan dalam memenangkan persaingan adalah dengan memiliki karyawan (SDM) yang kompeten dalam 
bidang pekerjaan dan berusia muda".
Berikut ini Gambar 7. memperlihatkan tema industri telekomunikasi berdasarkan pendapat pakar.

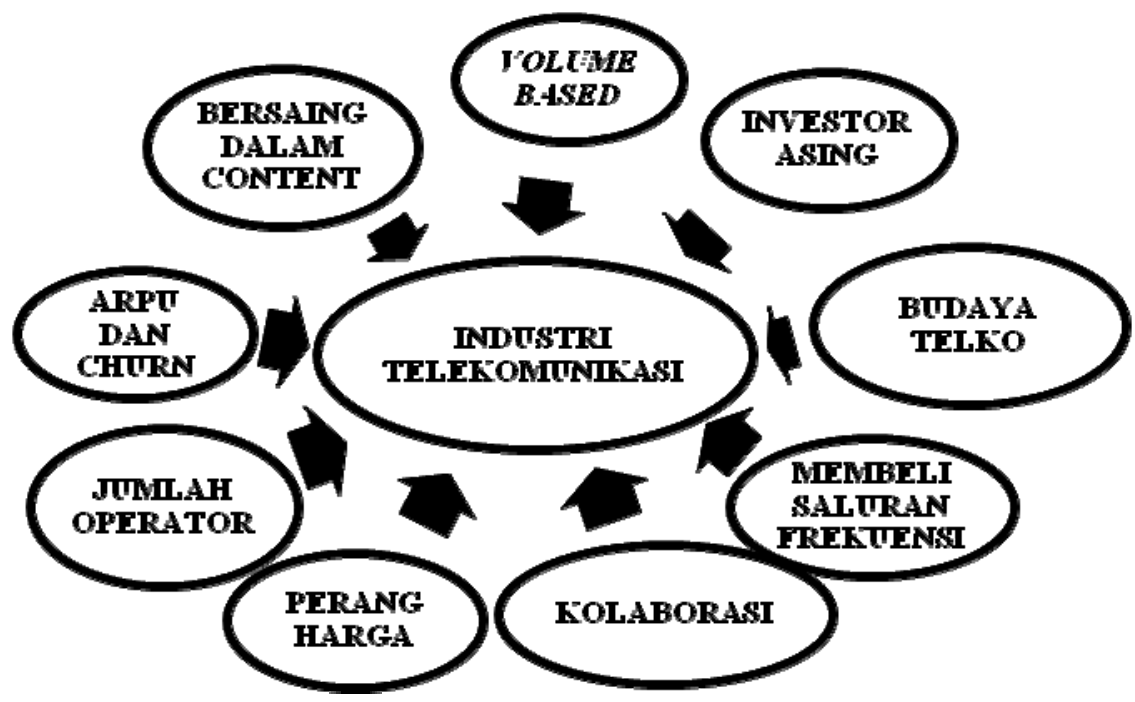

Gambar 7.

Tema : Industri Telekomunikasi

\subsection{Analisis Lima Kekuatan Porter}

Berdasarkan kajian data sekunder

dan pendapat pakar telekomunikasi Indonesia dapat diketahui bahwa, perkembangan industri telekomunikasi di Indonesia berkembang sangat pesat. Akan tetapi, berkembangnya industri telekomunikasi tidak dibarengi dengan roadmap kebijakan Pemerintah yang komprehensif, sehingga terjadi ketimpangan antara Pemerintah (regulator) dan para pelaku organisasi bisnis telekomunikasi (operator).

Pemerintah telah mencoba membuat roadmap industri telekomunikasi Indonesia, tetapi perkembangan teknologi dan aplikasi teknologi dibidang Information Communication \& Telecomunication (ICT) sangat dinamis dan luar biasa cepat berubah. Sementara pemerintah tidak terlalu mengikuti dinamika pasar, sehingga mengakibatkan terjadi gap-nya terlalu lebar.

\subsubsection{Ancaman Pendatang Baru}

Terdapatnya pendatang baru, tentu akan menambah tingkat kompetisi dalam industri telekomunikasi. Besarnya peluang pendatang baru ke dalam industri akan tergantung antara lain adalah dari (1) Kebijakan Pemerintah di bidang telekomunikasi, (2) Biaya investasi yang sangat besar merupakan salah satu penghalang yang cukup kuat untuk masuk kedalam industri telekomunikasi, (3) Diperlukan waktu yang panjang untuk mencapai cashflow positif, (4) Tingkat kemudahan jalur distribusi produk dan jalur pemasok merupakan tantangan bagi pendatang baru, dan tingkat loyalitas pelanggan yang telah dibina oleh para pemain/operator saat ini melalui kegiatan pemasaran dan promosi dengan biaya yang sangat besar, dan (5) Perkembangan teknologi yang berubah dengan cepat, menyebabkan para pendatang baru harus 
selalu uptodate terhadap teknologi baru agar tidak ketinggalan teknologi.

Dengan demikian ancaman masuknya pendatang baru dalam industri telekomunikasi bisa dikatakan relatif rendah.

\subsubsection{Daya Tawar Pelanggan (Pasar)}

Kondisi industri telekomunikasi Indonesia sedang mengalami transisi dan turbulensi industri telah memasuki fase kejenuhan (red ocean) yang mengakibatkan berubahnya perilaku pasar ke arah generasi baru, yakni C-Generation atau generasi terkoneksi (Connected Generation). Daya tawar pelanggan (pasar) pada industri telekomunikasi berperan dalam menekan harga turun.

Hal-hal yang dapat diidentifikasi dari kekuatan daya tawar pelanggan adalah: (1) Dengan semakin banyaknya jumlah pelaku organisasi bisnis telekomunikasi didalam industri ini memungkinkan pelanggan (pasar) dimanjakan dengan pelayanan yang berkualitas dengan harga yang relatif terjangkau, (2) Pelanggan (pasar) bebas mendapatkan informasi yang lengkap, mengenai demand, harga pasar yang sesungguhnya, sehingga tingkat tawar pelanggan (pasar) bisa disebut lebih tinggi manakala pelanggan (pasar) mempunyai informasi yang lengkap, karena dengan bekal informasi yang cukup, pelanggan ada pada posisi yang lebih tinggi untuk memastikan bahwa pelanggan telah mendapatkan penawaran harga yang terbaiknya (3) Tingginya tingkat sensitivitas pelanggan (pasar) terhadap perubahan harga, sehingga para operator perlu menawarkan harga yang relatif rendah kepada pelangganya.

Dengan demikian pelanggan (pasar) dalam industri telekomunikasi mempunyai daya tawar yang relatif tinggi dan sangat kuat.

\subsubsection{Ancaman Produk Substitusi}

Dalam industri telekomunikasi, "pembaruan teknologi” dirinya sendiri adalah "substitusi", sehingga hal tersebut merupakan bagian dari perubahan teknologi yang sangat cepat. Selain itu, sambungan telepon tetap, Wi-fi, Wimax, dan Internet dapat berfungsi sebagai produk substitusi. Pelanggan dapat menggunakan internet dimanapun dalam berinteraksi dan dapat menggunakan piranti yang sudah memiliki webcam atau menggunakan aplikasi untuk chatting seperti yahoo messenger.

Menggunakan ponsel dan pelayanan-pelayanan yang diberikan oleh para operator membuat lebih fleksibel dan mobile, sehingga mengakibatkan sedangnya tingkat perpindahan kepada produk substitusi lainnya.

\subsubsection{Daya Tawar Pemasok}

Dalam industri telekomunikasi, pemasok teknologi dan aplikasi teknologi, antara lain smartphone yang semakin canggih dan dengan harga yang terjangkau, juga dengan teknologi infrastruktur yang semakin canggih, seperti teknologi $3 G$ dan 4G (broadband ), mengarah pada kemampuan koneksi dan interkoneksi data dengan cepat dan berkualitas. Pemasok teknologi dari China mempunyai keunggulan dalam harga bila dibandingkan dengan pemasok dari Eropa dan Amerika. Pemasok terbesar dalam industri ini adalah perusahaan penyedia pembangunan infrastruktur dan jumlahnya banyak.

Daya kekuatan pemasok dapat dikatakan sedang, karena operator telekomunikasi selular dapat memilih pemasok yang bisa memberi manfaat, kualitas yang lebih dan harga yang terjangkau. 


\subsubsection{Persaingan dalam Industri}

Pada tahun 2011, terdapat 11 organisasi bisnis yang bergerak di bidang telekomunikasi selular di Indonesia. Sebagai perbandingan, Amerika Serikat, Eropa dan Australia tidak sampai memiliki lima perusahaan yang bergerak di bidang telekomunikasi selular, negara-negara di kawasan ASEAN dan ASIA lainnya antara lain Malaysia hanya dengan lima operator, Singapura tiga operator, dan China dua operator. Dengan jumlah operator telekomunikasi selular yang relatif banyak di Indonesia, maka mengakibatkan timbulnya persaingan yang ketat diantara para operator dalam memperebutkan pasar, sehingga diperlukan suatu strategi, inovasi produk dan layanan agar dapat tetap bertahan. Di samping persaingan diantara para pelaku industri, keempat kekuatan yang ada juga ikut berperang dalam meningkatkan persaingan itu sendiri.

Persaingan diantara pelaku indusrti telekomunikasi sangat dipengaruhi oleh: (1) Terdapatnya 11 pemain yang bergerak dalam teknologi GSM dan CDMA yang dengan kekuatan masing-masing dapat menaikkan intensitas dalam berkompetisi, (2) Produk yang ditawarkan oleh para operator cenderung sama atau mirip satu dengan yang lainnya (tidak ada diferensiasi) yang menyebabkan pelanggan membeli akan berdasarkan harga dan kualitas layanan, (3) Pertumbuhan yang lambat dikarenakan penetrasi pasar sudah mencapai 90\%, para pelaku berkompetisi dalam harga dan kualitas layanan, dengan tujuan untuk mendapatkan jumlah pelanggan yang banyak (volume), sehingga terjadi kejenuhan pasar yang dialami industri telekomunikasi saat ini, dan (4) Bervariasinya para pelaku industri (bergantung asal investor PMA perusahaan induknya) akan memiliki diferensiasi tujuan dalam berkompetisi.
Persaingan diantara pelaku bisnis organisasi telekomunikasi semakin ketat, untuk itu menuntut para pelaku organisasi bisnis telekomunikasi dipacu untuk berinisiatif meninjau ulang bisnis portofolionya, mengoptimalkan sumberdaya dalam meraih peluang yang ada, bergerak cepat untuk melakukan perubahan, baik dari sisi pelayanan pelanggan, pemasaran, produk, dan infrastruktur jaringan maupun budaya perusahaan.

Berdasarkan analisis-analisis tersebut di atas, maka dapat diindikasikan bahwa faktor pendorong (driver) yang substansial bagi terbentuknya turbulensi lingkungan industri adalah karena produk dan teknologi, serta pelanggan (pasar) yang semakin terdidik dengan menginginkan pelayanan yang berkualitas dan harga relatif terjangkau, yang telah menjadi pemicu para pelaku organisasi bisnis telekomunikasi selular untuk melakukan kegiatan pemasaran yang sistematis dan berkualitas, serta memberlakukan kebijakan harga yang kompetitif.

\subsection{Analisis Tingkat Turbulensi Lingkungan Eksternal Industri Telekomunikasi Selular}

Berdasarkan analisis lingkungan eksternal yang diperoleh dari data sekunder, pendapat pakar, dan persaingan diantara operator telekomunikasi selular, kemudian dapat dianalisis dan ditetapkan tingkat turbulensi lingkungan eksternal industri telekomunikasi selular. Turbulensi lingkungan organisasi bisnis merupakan kombinasi pengukuran atas: 1) changeability, yaitu kompleksitas lingkungan organisasi bisnis dan kebaruan relatif atas tantangan berkelanjutan yang dihadapi oleh perusahaan dalam lingkungan, dan 2) predictability merupakan kecepatan perubahan, rasio kecepatan dimana tantangan berganti dalam lingkungan dengan 
kecepatan respon perusahaan dan kejelasan masa depan, dimana ketepatan dan kesesuaian informasi tentang masa depan berperan penting. Selain aspek changeability dan predictability, terdapat aspek lain yang tidak kalah pentingnya untuk mengukur tingkat turbulensi lingkungan, yaitu aspek attributes lain yang digunakan seperti, frekuensi atas strategi pemasaran yang baru, tekanan pelanggan, tekanan pemerintah, diferensiasi produk, product life cycle, tingkat perubahan teknologi, dan faktor kritis kesuksesan inovasi. Masing-masing aspek dibahas secara mendalam pada bagian berikut ini.

\subsubsection{Changeability}

Kompleksitas organisasi bisnis telekomunikasi selular, ditandai dengan tingkat persaingan yang ketat, dikarenakan jumlah operator telekomunikasi selular lebih dari 10. Situasi persaingan yang ketat membuat organisasi bisnis dalam menyusun strategi bisnisnya, meskipun disusun secara jangka panjang, namun dalam perjalanannya dilaksanakan secara jangka pendek. Perubahan lain yang terjadi adalah terjadinya perubahan teknologi yang digunakan yaitu dari 2,75G menjadi 3G dan bahkan 4G. Hal tersebut disebabkan oleh terjadinya pergeseran penggunaan telepon selular dari voice dan SMS menjadi layanan data. Perubahan juga terjadi pada pemasok teknologi untuk infrastruktur, yang semula didominasi oleh pemasok dari Amerika dan Eropa, saat ini menggunakan pemasok dari Cina. Begitu juga devices yang digunakan adalah smartphone buatan Cina dengan harga yang lebih terjangkau. Secara lebih ringkas, dapat dilihat changeability industri telekomunikasi selular pada Gambar 8.

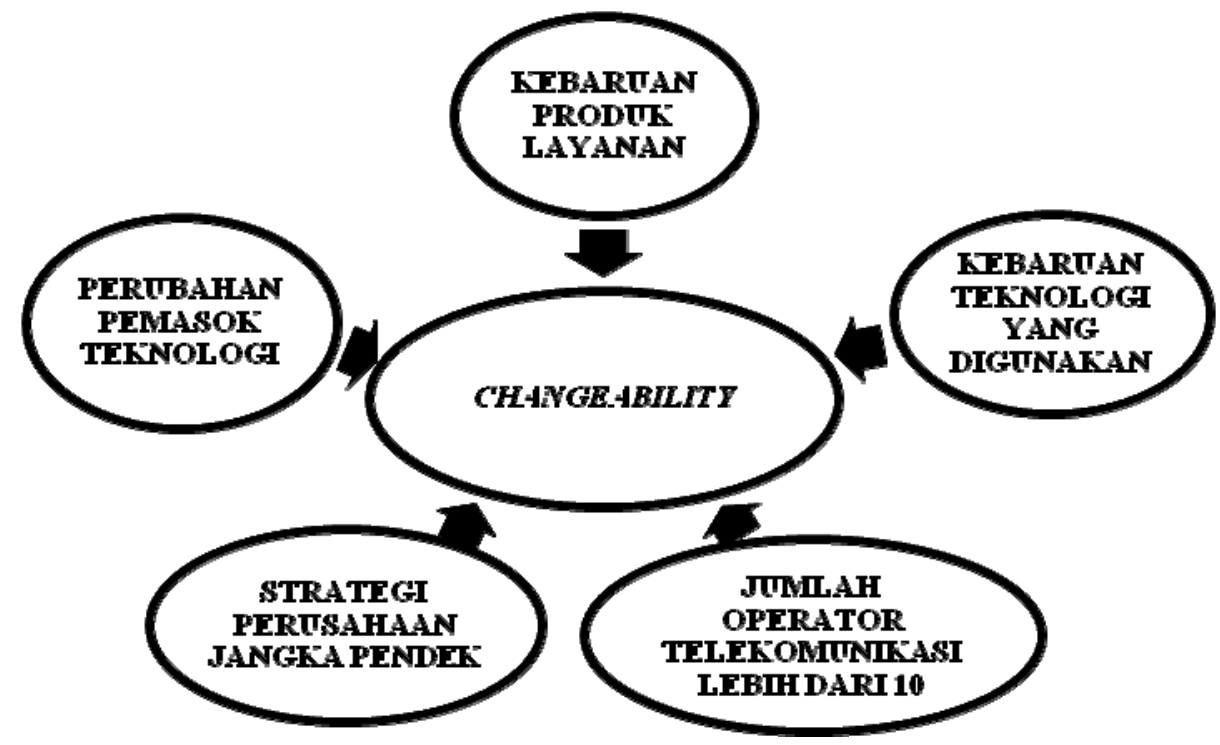

Gambar 8.

Aspek Changeability Industri Telekomunikasi Selular

\subsubsection{Predictability}

Kecepatan perubahan produk layanan atas permintaan pelanggan harus cepat ditanggapi oleh para operator telekomunikasi selular. Hal lain yang tidak bisa diprediksi oleh para operator telekomunikasi selular adalah tentang regulasi Pemerintah, seperti keputusan untuk 
mengimplementasikan LTE (Long Term Evolution atau 4G), dimana di Indonesia masih harus menunggu tahap sosialisasi dan pengaplikasian WiMAX terlebih dahulu. Belum lagi masalah alokasi frekuensi, dimana jalur frekuensi yang lazim digunakan oleh LTE di beberapa negara ialah $700 \mathrm{Mhz}$, di Indonesia frekuensi tersebut telah banyak digunakan untuk jalur pemancar media televisi dan radio. Beberapa operator bahkan sudah melakukan uji coba, namun dalam kenyataannya, teknologi tersebut masih harus menunggu sampai WiMAX benar-benar selesai di aplikasikan di seluruh wilayah Indonesia.

Upaya lain yang perlu dilakukan oleh organisasi bisnis telekomunikasi selular adalah kecepatan dalam menanggapi kebutuhan pelanggan, dengan menciptakan produk layanan yang inovatif, kreatif dan unik. Permasalahan yang dihadapi oleh operator telekomunikasi selular adalah sulit memprediksi apa yang akan dilakukan oleh pesaing, sehingga yang sering terjadi adalah organisasi cenderung bereaksi atas apa yang dilakukan oleh pesaing, sebagai akibatnya produk layanan yang dihasilkan oleh organisasi selular cenderung memiliki kemiripan. Begitu juga dengan daur hidup produk (product life cycle) yang cenderung semakin pendek, pelanggan cenderung tidak lagi loyal terhadap satu brand. Dengan demikian, organisasi bisnis telekomunikasi selular harus berupaya agar daur hidup produk akan lebih panjang. Secara lebih ringkas, dapat dilihat predictability industri telekomunikasi selular pada Gambar 9.

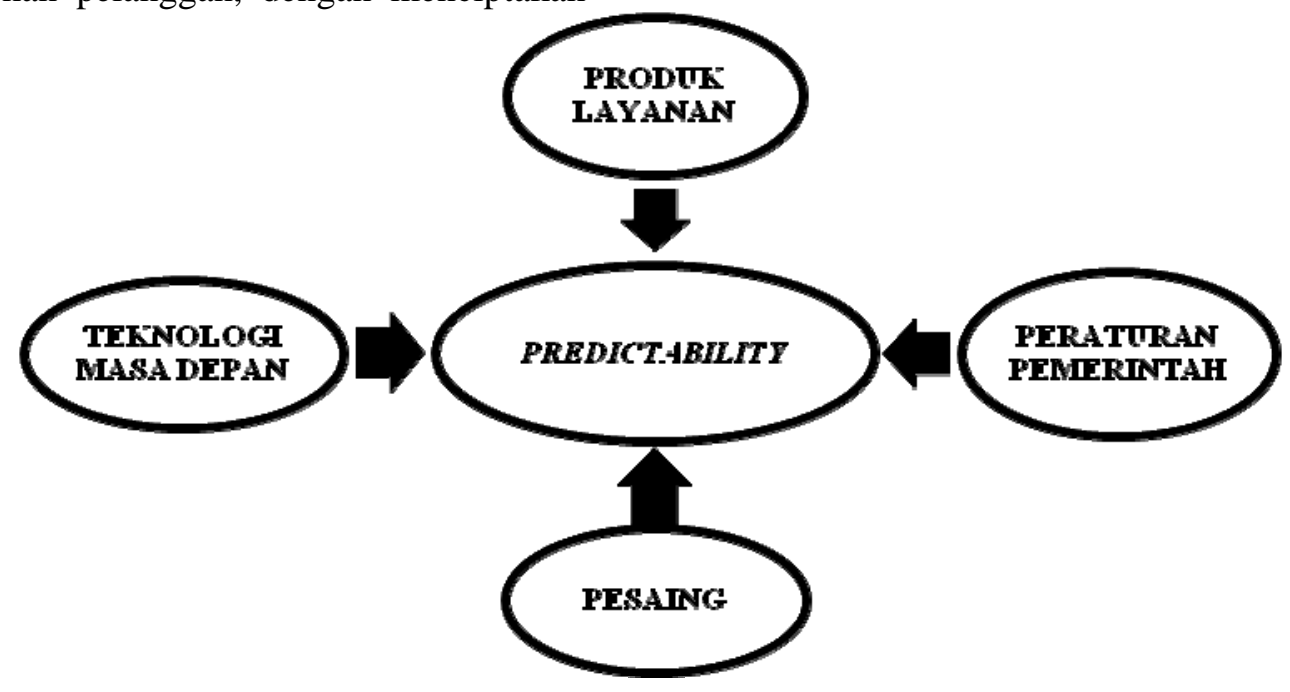

Gambar 9.

Aspek Predictability Industri Telekomunikasi Selular

\subsubsection{Atributes Lainnya}

Upaya untuk menentukan tingkat turbulensi lingkungan organisasi bisnis telekomunikasi selular digunakan atribut lainnya. Berikut ini analisis atas beberapa atribut yang digunakan dalam menentukan tingkat turbulensi lingkungan. a. Frekuensi atas strategi pemasaran yang baru

Pada organisasi bisnis telekomunikasi selular, cenderung frekuensi dalam merumuskan strategi pemasaran yang baru cukup tinggi. Perumusan strategi pemasaran dilakukan oleh organisasi telekomunikasi selular 
sebagai upaya untuk menyesuaikan dengan perubahan lingkungan terutama dengan mengetahui apa yang dilakukan oleh pesaing (reaktif).

b. Tekanan pelanggan

Tekanan pelanggan dalam industri telekomunikasi selular adalah tinggi. Hal tersebut diakibatkan karena pelanggan semakin cerdik dalam memilih dan menentukan operator telekomunikasi selular yang akan digunakan, umumnya melihat produk atau jasa yang kreatif dan inovatif, kualitas koneksi, luasnya jangkauan dan pelayanan. Sebagai akibatnya pelanggan mempunyai daya tawar yang tinggi dalam menentukan brand yang akan dipilih dan ada kecenderungan pelanggan tidak lagi setia pada satu brand, sehingga tingkat churn nya juga tinggi.

c. Tekanan pemerintah

Pemerintah sangat menentukan dalam menetapkan regulasi atau undang-undang yang akan diberlakukan pada industri telekomunikasi selular. Sebagai contoh, para operator telekomunikasi sudah siap untuk mengimplementasikan teknologi LTE, tetapi pemerintah belum mengijinkan teknologi tersebut diimplemantasikan. Begitu juga mengenai kebijakan mencabut premium SMS, yang berdampak pada pendapatan atau aspek keuangan organisasi bisnis.

d. Diferensiasi produk

Produk layanan yang yang dihasilkan atau diproduksi oleh operator telekomunikasi cenderung tingkat keragamannya sangat tinggi. Masingmasing operator menawarkan produk layanan yang cenderung memiliki kemiripan satu dengan yang lain (generic).

e. Product life cycle

Saat ini, posisi daya tawar pelanggan sangat tinggi, pelanggan dapat menentukan akan menggunakan SIM card dari operator yang dipilih. Biaya beralih yang rendah mengakibatkan pelanggan menjadi tidak "setia" pada satu brand saja. Hal tersebut mengakibatkan usia daur hidup suatu produk menjadi semakin pendek.

f. Tingkat perubahan teknologi

Tingkat perubahan teknologi dalam industri telekomunikasi selular terjadi dengan cepat. Sebagai contoh dari teknologi 2G bergeser menjadi 3G, sekarang akan memasuki teknologi 4G.

g. Faktor kritis kesuksesan inovasi

Para operator telekomunikasi selular, sangat meyakini bahwa organisasi dapat survive atau bertahan dan bahkan memenangkan persaingan apabila organisasi bisnis berhasil menciptakan produk yang inovatif, tidak hanya sekedar memenuhi kebutuhan pelanggan saja, tetapi juga menciptakan produk layanan baru yang dapat memberi manfaat bagi pelanggan dan juga bagi organisasi bisnis telekomunikasi selular.

Berdasarkan hasil analisis changeability, predictability, dan attributes turbulensi lingkungan organisasi bisnis, kemudian dapat ditentukan tingkat turbulensi lingkungan organisasi bisnis telekomunikasi selular seperti terlihat pada Tabel 4. 
Tabel 4.

Hasil Analisis Tingkat Turbulensi Lingkungan Organisasi Bisnis Telekomunikasi Selular

\begin{tabular}{|c|c|c|c|c|c|}
\hline Aspek & $\begin{array}{c}\text { Repetitif } \\
\text { (1) }\end{array}$ & $\begin{array}{c}\text { Expanding } \\
\text { (2) }\end{array}$ & $\begin{array}{l}\text { Changing } \\
\text { (3) }\end{array}$ & $\begin{array}{c}\text { Discontinuous } \\
(4)\end{array}$ & $\begin{array}{c}\text { Surprising } \\
\text { (5) }\end{array}$ \\
\hline Changeability & & & & $\mathrm{x}$ & \\
\hline Predictability & & & & $\bar{x}$ & \\
\hline \multicolumn{6}{|l|}{ Attributes } \\
\hline 1. Frekuensi strategi pemasaran baru & & & & Tinggi & \\
\hline 2. Tekanan Pelanggan & & & & Menuntut & \\
\hline 3. Tekanan Pemerintah & & & & "Menuntut & \\
\hline 4. Diferensiasi Produk & & & & Tinggi & \\
\hline 5. Product Life Cycle & & & & Pendek & \\
\hline 6. Tingkat Perubahan Teknologi & & & & Cepat & \\
\hline 7. Faktor kritis kesuksesan Inovasi & & & & Inovasi Produk & \\
\hline
\end{tabular}

Berdasarkan hasil pengukuran tingkat turbulensi lingkungan, maka dapat disimpulkan tingkat turbulensi lingkungan industri telekomunikasi selular ada pada tingkat discontinuous-strategic. Pada tingkat discontinuous-strategic, industri telekomunikasi selular memiliki karakter sebagai berikut: (1) frekuensi perumusan strategi pemasaran baru sangat tinggi, (2) pelanggan dan pemerintah menuntut (demanding), (3) diferensiasi produk tinggi, (4) product life cycle semakin pendek, (5) perubahan teknologi sangat dinamis dan teknologi sama sekali baru, dan (6) faktor kritis kesuksesan organisasi terletak pada tingkat inovasi yang dihasilkan.

\section{IMPLIKASI MANAJERIAL}

Hasil identifikasi tingkat turbulensi lingkungan dan analisis tantangan yang dihadapi para opearator telekomunikasi selular dapat digunakan sebagai masukan atau bahan pertimbangan bagi jajaran pemimpin dalam organisasi telekomunikasi selular dan memprioritaskan pilihan dari berbagai tantangan yang ada dan mengkaitkan atau memadukannya dengan rumusan strategi yang sudah disusun sebelumnya, mengantisipasi serta bagaimana seharusnya perusahaan melakukan rekayasa ulang.

\section{KESIMPULAN DAN SARAN}

\subsection{Kesimpulan}

Hasil analisis lingkungan industri telekomunikasi selular baik berdasarkan data sekunder maupun pendapat pakar, dan analisis model lima kekuatan dalam bersaing dapat disimpulkan tingkat turbulensi industri telekomunikasi selular yang dihadapi organisasi bisnis telekomunikasi selular pada tingkat discontinuous-strategic, dimana perubahan terjadi sangat dinamis dan masa depan bukan perpanjangan dari masa lalu, serta teknologi sama sekali baru.

\subsection{Saran}

Upaya meningkatkan daya saing industri telekomunikasi di Indonesia memerlukan kerjasama diantara para operator telekomunikasi itu sendiri dan dukungan pemerintah. Untuk itu pemerintah perlu mengeluarkan kebijakan-kebijakan yang dapat mendukung daya saing industri telekomunikasi selular, seperti peraturan yang mengatur standar mutu pelayanan, parameter penilaian kinerja operator telekomunikasi, pemberian tarif yang 
meringankan dalam pembayaran pajak, mengurangi pungutan-pungutan di daerah dan pengembangan teknologi yang dapat menunjang peningkatan kualitas pelayanan, jangkauan dan penetapan harga yang kompetitif, yang semuanya berujung pada peningkatan ARPU.

Perlu dilakukan penelitian lebih lanjut agar dapat memberi masukan yang bernilai tepat guna baik bagi para operator telekomunikasi dalam penyusunan strategi perusahaan dan pemerintah dalam menyusun kebijakan-kebijakan yang memberi manfaat baik bagi pemerintah maupun para operator telekomunikasi selular. 


\section{DAFTAR PUSTAKA}

Ansoff, I., \& Mc Donnell, E. 1990. Implanting Strategic Management. Englewood Cliffs, New Jersey : Prentice-Hall.

Choo, Chun Wei. 2001. Information management for the intelligent organization: the art of scanning the environment. 3rd ed. Medford, New Jersey : Information Today, Inc.

Dutta, Soumitra dan Mia, Irene. 2011. The Global Information Technology Report 2010-2011. Transformation 2.0. 10th Anniversary Edition. World Economic Forum.

Finlay L, 2006. Going Exploring: The Nature of Qualitative Research. Qualitative Research for Allied Health Professionals: Challenging Choices. Di dalam Linda Finlay and Claire Ballinger editor. New York: John Wiley \& Sons Ltd.

Gardiner, P dan Whiting,P.1997. "Success Factors in Learning Organizations : An Empirical Study". Industrial and Commercial Training. 29: 41-48.

George and Jones 2002. Organizational Behavior. $3^{\text {rd }}$ edition, Prentice Hall.

Hitt, W.D. 1996. "The Learning Organization: Some Reflections On Organizational Renewal”. Employee CounselingToday, 8:16.

Jamali, D. And Sidani, Y. 2008. "Learning organizations : diagnosis and measurement in a developing country context (The case of Lebanon)”.The Learning Organization. 15: 58-74. Emerald Group Publishing Limited.

Merriam SB. 2009. Qualitative Research: A Guide to Design and Implementation. John Wiley and Sons, Inc. San Franscisco: Published by Jossey-Bass. CA 94103-1741.

Peters, Thomas, J. dan Waterman, Robert, H.1982. In Search Of Excellence: Lessons From America's BestRun Companies. New York : Harper \& Row.

Pool, S.W. 2000. "The Learning Organization: Motivating Employees By Integrating TQM Philosophy In A Supportive Organizational Culture”. Leadership and Organization Development Journal, 21:373-8.

Porter, M.E. 1980. Competitive Strategy. New York : Free Press.

Rachmat, Iwan 2011. Konsolidasi Sebagai Solusi Atas Tantangan yang Dihadapi Para Operator Selular. http://blog.mobilemonday.co.id.

Rajagopal, Jayashree 2011. Globalisation and Consolidation of the Telecom Industry: Mobile and Wireless Perspective. Frost \& Sullivan. http://blog.mobilemonday.co.id [20 Januari 2012]. 